\title{
IMPACT OF AIR POLLUTION ON PROPERTY VALUES : A HEDONIC PRICE STUDY
}

\author{
Endah Saptutyningsih \\ Fakultas Ekonomi Universitas Muhammadiyah Yogyakarta \\ Jalan Lingkar Selatan, Tamantirto, Kasihan, Bantul, Yogyakarta \\ E-mail: end_naufal@yahoo.com
}

Diterima 30 Februari 2013 / Disetujui 4 April 2013

\begin{abstract}
The main purpose of this study is the calculation of implicit prices of the environmental level of air quality in Yogyakarta on the basis of housing property prices. By means of Geographical Information System, the housing property prices characterized from the area which have highest air pollution level in province of Yogyakarta. Carbon monoxide is used as the pollution variable. The methodological framework for estimation is based on a hedonic price model. This approach establishes a relationship between the price of a marketable good (e.g. housing) and the amenities and characteristics this good contains. Therefore, if variations in air pollution levels occur, then households would change their behavior in an economic way by offering more money for housing located in highly improved environmental areas. The hedonic regression results that the housing price decrease while increasing the level of air contamination such substance as carbon monoxide.
\end{abstract}

Keywords: air pollution, hedonic price, property value, marginal willingness to pay curve JEL: Q53

\begin{abstract}
Abstrak: Tujuan utama studi ini menghitung harga implisit dari tingkat kualitas lingkungan udara di Yogyakarta dengan berbasis pada harga properti perumahan. Dengan menggunakan sistem informasi geografis, harga properti perumahan dicirikan dengan daerah yang memiliki tingkat polusi udara tertinggi di provinsi Yogyakarta. Karbon monoksida digunakan sebagai variabel polusi. Kerangka metodologis untuk estimasi didasarkan pada model harga hedonis. Pendekatan ini menetapkan hubungan antara harga barang yang dipasarkan (misalnya perumahan) dan fasilitas dan karakteristik barang. Oleh karena itu, jika terjadi variasi dalam tingkat polusi udara, maka rumah tangga akan mengubah perilaku mereka secara ekonomi dengan menawarkan lebih banyak uang untuk perumahan terletak di daerah lingkungan yang baik. Hasil regresi hedonis menunjukkan bahwa penurunan harga perumahan akan menaikkan tingkat pencemaran udara seperti misalnya karbon monoksida.
\end{abstract}

Kata kunci: polusi udara, harga hedonis, nilai properti, kurva kesediaan marjinal membayar JEL: Q53

\section{INTRODUCTION}

Urban pollution is a major focal point of public health concern and regularity activity (WHO, 2002). Pertinent guidelines and effective interferences require knowledge of the burden of sickness and premature deaths attributable to specified pollutants. A long-term worldwide research program is focusing on effects of par- ticulates and other criteria pollutants such as $\mathrm{NO}_{2}, \mathrm{O}_{3}$ and $\mathrm{CO}$ (Brunekreef and Holgate, 2002).

Among several tribes of valuation methods, the hedonic price technique has been widely used to assess the effect of urban air pollution on property values in developed urban centers. Unfortunately, applications addressed for developing urban centers are rare, and very little known about the effect of air 
pollution on household's welfare in cities such as province of Daerah Istimewa Yogyakarta. Carbon monoxide (CO) emitted by motor vehicles are the main concern because of high visibility of effect compared to other pollutants. Nonetheless, empirical studies on air-pollution related to welfare effects were rare. Therefore, the objective of this study is to identify the highest level of air pollution (especially CO) in Daerah Istimewa Yogyakarta and estimate household marginal willingness to pay for air quality improvement in the province of Daerah Istimewa Yogyakarta. This study applied the hedonic method to province of Daerah Istimewa Yogyakarta which should serve as a suitable laboratory for this method given the variation in pollution levels within the region, and the simplicity of the common housing types.

There are many centers of commerce and education that support the local economy in Daerah Istimewa Yogyakarta. The pollution problems arise due to the increasing number of motor vehicles which lead to imbalance of the number of motor vehicles with the capacity of the highway. So these cause the congestion, noise and air pollution problems. The number of vehicles in the province of Daerah Istimewa Yogyakarta (DIY) always increased from year to year. From 2000 to 2010 the number of motor vehicles has increased on average by 9.02 percent. This is because of the impact of the increasing number of motor vehicles. Therefore, it is necessary to map the region for identifying the areas that need to be prioritized for reducing levels of air pollution. The largest number of vehicles in 2010 in Sleman District is about 493800 units, followed by the city of Yogyakarta as many as 367,957 units. The motorcycle dominate the streets of the five district/city in DIY. The number of motorcycles for 87.75 percent of all vehicles in the province of Yogyakarta. Sleman District has the highest number of vehicles in the province of DIY, motorcycle as much as 87.4 percent of all vehicle types in the district of Sleman, while the motorcycle as much as 83.9 percent of all types of vehicles in the city of Yogyakarta.

Residential property prices have increasingly been influenced by the quality of air and its deterioration therefore, affects urban prop- erty values. In most of industrial cities the world over, consumers express their strong preferences for environmental amenities such as improved air quality and are even willing to pay for such improvements. Consumer's WTP in turn has been influenced by structural characteristics like size of plot, number of rooms, garage space, central heating etc., public and socioeconomic characteristics like social security, quality of schools, racial composition, rate of employment, etc. and local amenities like environmental quality, access to services, communication, etc. (Parikh, et.al.,1994; Murty and Surendar Kumar, 2002 in P.K.Baby, 2003). Although all these factors influence the choices of consumers, the primary concern of this inquiry is to unearth how the quality of air influences property values.

The Hedonic Pricing Method applies a related market approach to acquire the value of an environmental amenity from indirect observations (Rosen, 1974). Economic theory indicates that in certain circumstances, it is possible to separate the effects of various attributes of a good in ways by which they affects individual's utility. For many environmental goods, it is often possible for individuals to choose levels of consumption through their choices. For instance, in a decision to buy a home, there is an implicit market for environmental quality. The demand for non market environmental goods such as air quality affects observed prices and consumption of other market goods. The most commonly applied model to measure this relationship is the hedonic price model of environmental valuation.

For measuring the exposure to air pollution requires simplifications and assumptions that have limitations. The size of ambient pollution is taken in a small number of stations and rarely recorded continuously and even more fickle urban population, so the assumption must be made to estimate personal exposure. There are a variety of pollutants from time to time and space because of such factors as the source of meteorology, topography and emission. Ecological studies in the United States taking measurements of pollutants for a period of two weekly (Love and Seskin, 1972) or quarterly (Ozkaynak and Thurston, 1987). Gauges are 
changed from time to time depending on its cities, and have little reliability. Therefore it is necessary to assume the data to a single point representing a wide geographical area.

More recently, an understanding of the complex urban air quality has been reinforced by adopting urban air shed model. This model calculates the spatial and temporal variations and differences in the reactivity of air pollutants that can provide detailed spatial picture of pollutant levels. When combined with GIS techniques, this model can improve the measurement of exposure in relation to health (Cicero-Fernandez et al, 2001; Hoek et al, 2001).

The development of spatial data management within the framework of geographic information systems (GIS) has created a new era of environmental modeling. More powerful computers have made the air quality model run at the global and local spatial scale as possible. In order to understand the function of more complex models, modeling system should be composed of other subsystems (point and area sources of pollution, the description of the spatial height of the area, meteorological data and air quality monitoring network).

More recently, the use of GIS has become essential in providing the boundary with air quality models. Many models have been combined with GIS to simulate various environ- mental processes such as those described in books written by Longley et al. (2001). In the case of a scale model of the air, the data is more detailed about the room needed to include the effects of buildings and other man-made on the distribution of air pollutants, (Janour, 1999). Apart from this approach, statistical theory is also used to demonstrate the spatial-temporal interactions as described by Briggs et al. (2000).

Based on the background above, this study will identify the highest polluted area in Yogyakarta by using Geographic Information System (GIS) approach. It is expected to estimate the benefits to local households to reduce air pollution in the district / city in the province of Daerah Istimewa Yogyakarta (DIY). Total benefits consisting of health benefits, and the benefit of the environmental ease of reducing urban air pollution can be estimated using the model of hedonic property value model.

The table 1 presents some summary of related research studies will be conducted.

\section{RESEARCH METHOD}

Standard procedure in designing and using GIS, namely: data collection, preliminary data processing, database construction, analysis and spatial analysis, and presentation graphics.

Table 1. Previous Studies

\begin{tabular}{|c|c|c|c|}
\hline No. & Name & Methods & Results \\
\hline 1 & Sh.Rahmatizadeh et.al & GIS & $\begin{array}{l}\text { The system developed as an environmental decision } \\
\text { support system (EDSS) can be used effectively to monitor } \\
\text { and manage the different pollutants }\end{array}$ \\
\hline 2 & $\begin{array}{l}\text { Gualtieri dan } \\
\text { Tartaglia (1998) }\end{array}$ & GIS & $\begin{array}{l}\text { GIS models are suitable for use by local governments to } \\
\text { predict the conditions pollution levels in urban areas, } \\
\text { integrating monitoring network measurements, and } \\
\text { estimate the sensitivity level of pollution for the variable } \\
\text { distribution of traffic flow and air condition }\end{array}$ \\
\hline 3 & Cowell \& Zeng (2003) & GIS & $\begin{array}{l}\text { Integrating uncertainty theories with GIS for modeling } \\
\text { areas vulnerable to climate change }\end{array}$ \\
\hline 4 & Murty et.al (2003) & Hedonic price & $\begin{array}{l}\text { There is a positive relationship between marginal WTP } \\
\text { and the income and education }\end{array}$ \\
\hline 5 & Moaz (2005) & Hedonic price & $\begin{array}{l}\text { Pollution levels reduce property values. Average MWTP } \\
\text { for any decrease in the concentration of TSP is U.S. \$ } 60.00\end{array}$ \\
\hline 6 & Bajari, P. (2006) & Hedonic price & $\begin{array}{l}\text { The amount of money that households would be paid for } \\
\text { each one unit reduction in PM10 concentrations had a } \\
\text { median of } \$ 149 \text { to } \$ 185\end{array}$ \\
\hline
\end{tabular}


Table 2. Main Activity Procedures in SIG

\begin{tabular}{|c|c|}
\hline Provision of data & $\begin{array}{l}\text { - Obtained on the number of maps and documents including data } \\
\text { coding, data verification and error correction } \\
\text { Describe the collection of existing data, particularly data on } \\
\text { geographical conditions such as high surface soil, land use, data } \\
\text { on administrative regions, CO concentration. These data can be } \\
\text { obtained from various sources such as the Central Bureau of } \\
\text { statistics related, Meteorology and Geophysics Agency, the Local } \\
\text { Government of each district in DIY } \\
\text { - Carrying out primary survey }\end{array}$ \\
\hline Preparation of data processing & $\begin{array}{l}\text { - Interpret or classify data that can be of a survey } \\
\text { - Develop a digital data structure to select the model of spatial / } \\
\text { space (Based on an object, network, and field) } \\
\text { Transforming / change the coordinate system used to be } \\
\text { common }\end{array}$ \\
\hline $\begin{array}{l}\text { Constructing basic data or } \\
\text { databases ( data storage and call } \\
\text { back data) }\end{array}$ & $\begin{array}{l}\text { - } \quad \text { Creating a model of the concept of data } \\
\text { - } \quad \text { Establish a data base structure } \\
\text { - } \quad \text { Sending data to database }\end{array}$ \\
\hline $\begin{array}{l}\text { The study of spatial / location / } \\
\text { region along with the analysis }\end{array}$ & $\begin{array}{l}\text { - } \quad \text { Call data based on location } \\
\text { - } \quad \text { Call data based on class or attribute } \\
\text { - } \quad \text { Finding the most suitable locations based on criteria } \\
\text { - } \quad \text { Creoking for patterns, groups, lines, and interaction } \\
\text { phenomena }\end{array}$ \\
\hline $\begin{array}{l}\text { Graphical Display (Visualization } \\
\text { and interaction) }\end{array}$ & $\begin{array}{l}\text { - } \quad \text { Creating maps } \\
\text { - } \quad \text { Exploring data } \\
\text { - } \quad \text { Creating three-dimensional view } \\
\text { report }\end{array}$ \\
\hline
\end{tabular}

Source: Adapted from Jones (1996)

These data are included to adjust the needs analysis, course of study.

Each region has a unique and dynamic series of potential hazards. When certain areas are known to have known vulnerabilities and inhabited by many people, it can be done immediately act to reduce the losses incurred. According to Connors (2006), GIS can be used to access the potential risks that might occur. GIS unit integrates different data to provide a rough picture of the impact of air pollution on society.

\section{Modeling of Air Pollution Using Kriging Technique}

Kriging is group of geostatistical techniques for interpolating the value of a random field (e.g., elevation, z, of the landscape as a function of geographic location) in locations that are not observable from the observed value at a nearby location.

The theory of Kriging interpolation and extrapolation to be developed by the French mathematician Georges Matheron based on a Master's thesis Gerhardus Daniel Krige. Kriging including linear least squares estimation. As illustrated in Figure 3, the goal of Kriging is to estimate the value of a real-valued function of the unknown, $\mathrm{f}$, at some point, $\mathrm{x}$ *, given the values of the function at some other point, $x 1$, ..., xn. A kriging estimator is said linear because the predicted value is a linear combination which can be written as

$$
\begin{aligned}
& \hat{f}\left(x^{*}\right)=\sum_{i=1}^{n} \lambda_{i}\left(x^{*}\right) f\left(x_{i}\right) \\
& \varepsilon(x)=F(x)-\sum_{i=1}^{n} \lambda_{i}(x) F\left(x_{i}\right)
\end{aligned}
$$

Weight $\lambda i$ is the solution for a system of linear 
equations obtained by assuming that $\mathrm{f}$ is a sample path of the random process $\mathrm{F}(\mathrm{x})$ and prediction error should be minimized in some sense. For example, the assumption is that the simple kriging mean and covariance of $F(x)$ is known and then, kriging predictor is one that minimizes the variance of the prediction error.

\section{Hedonic Price Analysis}

The hedonic price technique is a method for estimating the welfare effects of environmental assets and services by estimating the influences of environmental attributes on property value. The hedonic price theory assumes that as environmental quality changes, property prices would also change, indicating a scope for estimating an implicit demand function for the environmental goods by observing the property price variations. So hedonic prices are defined as the implicit prices of the attributes and are revealed to economic agents from observed prices of differentiated products and the specific amounts of characteristics associated with them (Banarjee,S. in Bhattacharya, 2002).

Following the general principles of consumer's behavioral theories, decisions in property markets are governed by demand supply interactions. The basic hedonic property model can be explained as given below.

Let the price of $\mathrm{i}^{\text {th }}$ residential location (PPRICE) be

$$
\operatorname{PPRICE}_{\mathrm{i}}=\operatorname{PPRICE}\left(\mathrm{S}_{\mathrm{i}}, \mathrm{N}_{\mathrm{i}}, \mathrm{E}_{\mathrm{i}}\right)
$$

where, $S_{i}$ is structural characteristics, $N_{i}$ is neighbourhood characteristics, $E_{i}$ is environmental characteristics

Consider the utility function of the individual who occupies house $i$ as

$u\left(X, S_{i}, N_{i}, E_{i}\right)$

where, $\mathrm{X}$ represents composite private good that is taken as a numeraire. Assume that preferences are weakly separable in housing and its characteristics. The individual maximizes (2) subject to the budget constraint,

$M=X+$ PPRICE the first order condition for choice of environmental amenity $q j$ is given as,

$\frac{\partial u / \partial q i}{\partial u / \partial x}=\frac{\partial P P R I C E i}{\partial q j}$

The partial derivative of (1) with respect to one of the environmental quality characteristics qj, (air quality), give the implicit marginal price of that characteristics.

In the second stage, MWTP for environmental quality is expressed as a function of $q j$, given $S_{i}, N_{i}, E_{i}^{*}$ and $W_{i}$, where $E_{i}{ }^{*}$ is the vector of other environmental characteristics and $W_{i}$ is socioeconomic characteristics.

$b_{i j}=b_{i j}\left(q_{j}, E_{i}^{*}, S_{i}, N_{i}, W_{i}\right)$

Equation (5) gives the individual's MWTP for the improvement in environmental quality $q j$.

\section{RESULTS AND DISCUSSION}

\section{Analysis of the Geographical Information System}

Mapping with Kriging technique is performed at several sample points in the province of Daerah Istimewa Yogyakarta. Some point locations can be seen in the Figure 1 in Appendix.

WHO (1992) states that at least 90 percent of carbon monoxide (CO) in urban air come from vehicle emissions. The levels of carbon monoxide (CO) in urban areas are quite varied depending on the density of motor vehicles that use gasoline. In general, the maximum $\mathrm{CO}$ levels at peak hours in the morning and evening. The variations of $\mathrm{CO}$ levels are also influenced by the varied topography and the surrounding buildings. Impact of CO poisoning is very dangerous for people who have suffered heart muscle disorder or severe peripheral circulation.

$\mathrm{CO}$ levels at several locations in the province of Yogyakarta also found from vehicle exhaust emissions that increasingly crowded, and the lack of strict control of the drains which exhaust smoke. It can be assumed that the more vehicles accounted for the higher levels of $\mathrm{CO}$ in the air, so that the higher level of $\mathrm{CO}$ in air 
pollution

Based on the monitoring results of the concentration of $\mathrm{CO}$ in four counties and the city of Yogyakarta by using the Kriging technique, it can be mapped the areas which have the highest concentration of $\mathrm{CO}$ in the province of Daerah Istimewa Yogyakarta (see Figure 2).

In the province of Yogyakarta (DIY), the areas that have the highest concentration of $\mathrm{CO}$ in Sleman regency are Depok, Ngaglik and Kalasan sub-districts. While in the city of Yogyakarta include Jetis, Gondomanan, Wirobrajan, Kraton, Mantrijeron sub-districts, and in parts of Ngampilan, Gedongtengen, and Mergangsan sub-districts (see Figure 3 in Appendix).

By overlapping between isoconcentration maps of $\mathrm{CO}$ parameter with a map of the building in the areas which have the highest concentration of $\mathrm{CO}$ in the province of Yogyakarta, it would be found the region has a concentration of CO in Sleman regency. It covering Kalasan sub-district that have the building blocks relatively small compared with Depok sub-district which is also has the highest concentration of $\mathrm{CO}$ in the province of Yogyakarta. There are many building blocks in Depok sub- district because there are many residential and educational centers and services.

While in the city of Yogyakarta - which is also has the highest concentration of $\mathrm{CO}$ in the province of DIY - is almost entirely dominated by the building blocks because in the areas such as Jetis, Gondomanan, Wirobrajan, Kraton, and Mantrijeron sub-districts heve many economic activities. Many building blocks in the city of Yogyakarta showed by the overlay map between isoconcentration of $\mathrm{CO}$ parameter and public facilities (see Figure 4 in Appendix) in which there are many services and health centers in Jetis sub-district. While in Gondomanan, Wirobrajan, Kraton, and Mantrijeron sub-districts, there are many industries and services and some health centers. Many centers of economic activity and other public facilities require vehicles which exhaust $\mathrm{CO}$ gas. In addition, combustion products generated from industries can also cause high concentrations of $\mathrm{CO}$ in the region.

The higher vehicle's exhaust and combustion products that are not offset by the presence of green open space causes the concentration of $\mathrm{CO}$ in the city of Yogyakarta relatively high. It

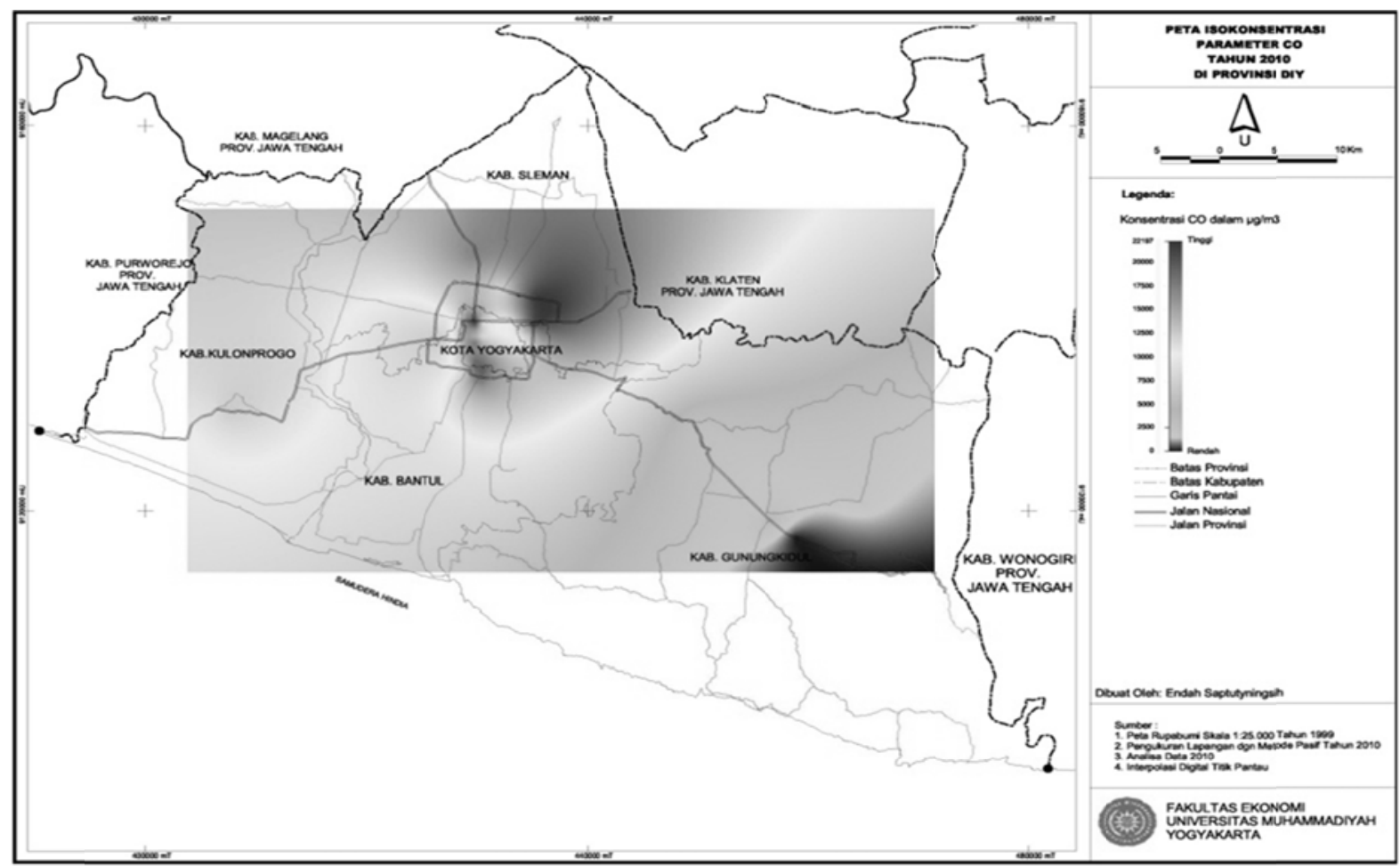

Figure 2. Isoconcentration Map of CO in the Province of DIY 
Table 3. Description and Summary Statistics of Variables

\begin{tabular}{llrr}
\hline \multicolumn{1}{c}{ Variabel } & \multicolumn{1}{c}{ Description } & \multicolumn{1}{c}{ Mean } & Stand.Deviation \\
\hline PPRICE & Sales price of house (Rupiahs) & $3 \mathrm{E}+008$ & 243617628.2 \\
LANDSIZE & Plot area $\left(\mathrm{m}^{2}\right)$ & 206.05 & 198.288 \\
BUILDSIZE & Building area $\left(\mathrm{m}^{2}\right)$ & 124.28 & 111.246 \\
NUMROOM & Number of rooms (units) & 4.00 & 4.614 \\
WSTRUCTDUM & Dummy structure of wall & 1.15 & 0.497 \\
DISSCHOOL & Distance from school $(\mathrm{m})$ & 512.94 & 555.328 \\
DISHPITAL & Distance from hospital $(\mathrm{m})$ & 956.26 & 802.810 \\
DISSPMARKET & Distance from supermarket $(\mathrm{m})$ & 990.68 & 867.411 \\
DISREST & Distance from restaurant $(\mathrm{m})$ & 642.64 & 785.568 \\
DISCITY & Distance from city $(\mathrm{m})$ & 2062.04 & 1592.980 \\
DISMSTREET & Distance from mainstreet $(\mathrm{m})$ & 192.01 & 165.511 \\
GARDENDUM & Dummy for close to garden or not & 1.79 & 0.407 \\
INCOMEDUM & Dummy for level of income & 1.88 & 0.509 \\
FAMEMBER & Number of family members $($ people) & 3.92 & 1.356 \\
CO & Concentration of CO $\left(\mu \mathrm{g} / \mathrm{m}^{3}\right)$ & 16060.00 & 4054.894 \\
\hline
\end{tabular}

can be shown in Figure 5 in which the region of Yogyakarta is still rare green open space.

Unlike the city of Yogyakarta, and Ngaglik Depok sub-districts have abundant green open space, although in certain areas there is no green space leading to high concentrations of $\mathrm{CO}$ in the region. This is also compounded by the many education centers, health and industries are clustered in certain areas (see Figure 5 in Appendix).

\section{Data Description}

Results of mapping with GIS methods conclude that the areas which have the highest concentration of $\mathrm{CO}$ in the city of Yogyakarta include Jetis, Gondomanan, Wirobrajan, Kraton, and Mantrijeron sub-districts. In addition, some sub-districts such as Ngampilan, Gedongtengen, and Mergangsan in part also have relative high concentrations of CO. In Sleman regency, some sub-districts such as Depok, Ngaglik and Kalasan are also relatively have high $\mathrm{CO}$ concentrations.

In order to estimate a hedonic price function, it is necessary tp gather data on all characteristics that relevant to the sales prices of the house. The explained variable, price of house, is considered as a function of environmental, structural, and neighbourhood variables and these data sets relate to the residential areas of mapping results by GIS above. Data from 250 households were collected using a structured questionnaire.

The table 3 shows that the average house price is 300 million rupiahs. Area of house is one of the important variables affecting house prices. The average area of land is 206.5 square meters. The average area of building is 124.28 square meters. Another factor which influences residential property price is the number of rooms that a house has. The average number of rooms observed for houses in the study area is four.

Among the 'neighborhood variables', six major ones - distance from school, distance from hospital, distance from supermarket, distance from restaurant, distance from the city, distance from main street - are also considered for this analysis. The distance calculated is that from the residence of the household to the nearest location related. The average distance from school is 512.94 meters. The distance from the nearest hospital is 956.26 meter on average. The average distance from main street is 192 meters.

One of the 'socioeconomic variables' is the number of family member. The average number of family member is four people.

In the hedonic price model that we adopt in this study, the concentration of $\mathrm{CO}$ is taken 
as measure of air quality. The data used comes from ambient air quality monitoring of Badan Lingkungan Hidup of DIY. The ambient air quality for the year 2010 is $16060 \mu \mathrm{g} / \mathrm{m}^{3}$ on average.

\section{Estimation of the Model}

Estimation of the Hedonic Model was undertaken in two stages (Rosen, 1974). In the first stage, the hedonic property price function was estimated and the implicit prices were computed for all the observations. In the second stage, implicit demand function or the marginal willingness to pay function was derived from the hedonic price function for given sets of environmental characteristics. The procedure is explained below.

(1) Specification of the Hedonic Price Function The hedonic price function relates price of residential property to the structural, neighborhood and environmental characteristics of the property (Murty, 2003) $)^{1}$ and is estimated using a simple least square regression model. Following this general specification and refining it by dropping insignificant variables, the hedonic price function is estimated as follows.

$$
\begin{aligned}
\ln \text { PPRICE }= & a_{0}+a_{1} \ln \text { LANDSIZE }+a_{2} \ln \\
& \text { BUILDSIZE }+a_{3} \ln \text { DISSCHOOL }+ \\
& a_{4} \ln \text { DISHOSPITAL }+a_{5} \ln \text { CO }+e
\end{aligned}
$$

where, In PPRICE is natural log of property price, In LANDSIZE is natural log of plot area, $\ln$ BUILDSIZE is natural log of building area, $\ln$ DISSCHOOL is natural log of distance from school, In DISHOSPITAL is natural log of distance from hospital, In CO is natural log of CO

The partial derivative of this function with respect to air quality gives its implicit marginal price. This price is the additional amount which the household would be willing to pay for

\footnotetext{
${ }^{1}$ The model is specified as follows: $L n P h_{i}=\beta_{0}+\Sigma \beta_{j} S_{j i}+\Sigma \beta_{k} Q_{k i}+\Sigma \beta_{l} N_{l i}+\varepsilon_{l}$, where, $\mathrm{i}=1,2, \ldots, \mathrm{n} ; \mathrm{S}_{\mathrm{i}}=$ structural characteristics, $\mathrm{N}_{\mathrm{i}}=$ neighbourhood characteristics, $\mathrm{Q}_{\mathrm{i}}=$ environmental characteristics From the above hedonic price function, implicit price(s) of environmental characteristic (s) is calculated. First partial derivative of the hedonic price function with respect to environment quality provides the implicit price.
}

choosing a house with reduced amounts of air pollution, other things remaining the same. The marginal implicit price is estimated as follows.

$$
\text { implicit price } C O=P P R I C E .\left(\frac{1}{C O}\right) a 5
$$

(2) Specification of the Implicit Demand

\section{Function}

Estimated implicit prices for different sites correspond to the individual willingness to pay (WTP) for a marginal unit of environmental good purchased. The individual chooses the level of characteristic at which their Marginal Willingness To Pay (MWTP) for that characteristic is equal to its implicit marginal price. The inverse demand function is then obtained by regressing implicit price as a function of air quality, $\mathrm{CO}$, and other socio economic features of individuals along with a demand shift variable, such as income. The regression equation for inverse demand function in general is:

$$
\begin{aligned}
& \operatorname{lnIMPPRICE}=b_{0}+b_{1} Y+\Sigma b_{2} \text { sosec }+\Sigma b_{3} \\
& \text { struc }+\Sigma b_{4} \text { neigh }+\Sigma b_{5} e n v+u
\end{aligned}
$$

where, $Y$ is the annual income of the household, sosec is the social economic characteristics, struc is the structural characteristics, neigh is neighbourhood characteristics, and env is environmental characteristics.

However, if some or many of structural characteristics were not significant, these factors could be neglected while specifying the relation. So after omitting the insignificant variables through trial and error method, the implicit price function considered for final estimation is:

$$
\begin{gathered}
\operatorname{lnIMPPRICE}=b_{0}+b_{1} \text { INCOMEDUM + } \\
b_{2} \ln \text { LANDSIZE }+b_{3} \ln \text { BUILDSIZE + } \\
b_{4} \ln \text { DISSCHOOL }+b_{5} \text { DISHPITAL }+ \\
b_{6} \ln \text { CO }+\varepsilon
\end{gathered}
$$

where, In IMPPRICE is natural log of implicit price; INCOMEDUM is level of income.

\section{Empirical Results and Interpretation}

In the estimation of hedonic price equation, we assume a negative relationship between envi- 
ronmental characteristic $\mathrm{CO}$ and the property price. All the structural parameters included in the model, like plot area and building area, are expected to have positive relations with the property price. Neighborhood characteristics like distance from school and hospital are inversely related with property price. It is normally expected that as distance from hospital and school increases, property price decrease, where as distance from city increases property price also increases. Applying these assumptions on the model specified above, the parameters are estimated using the method of ordinary least squares and is given in Table 4.

Table 4. Regression Result of Hedonic Price Function

\begin{tabular}{|c|c|c|}
\hline Variable & Full Model & Fit Model \\
\hline (Constant) & $\begin{array}{c}3.323 \\
(3.509)^{* * *}\end{array}$ & $\begin{array}{c}2.783 \\
(3.178)^{* * *}\end{array}$ \\
\hline LnLANDSIZE & $\begin{array}{c}0.553 \\
(7.840)^{* * *}\end{array}$ & $\begin{array}{c}0.528 \\
(7.658)^{\star * *}\end{array}$ \\
\hline LnBUILDSIZE & $\begin{array}{c}0.113 \\
(1.380)\end{array}$ & $\begin{array}{c}0.164 \\
(2.093)^{\star *}\end{array}$ \\
\hline LnNUMROOM & $\begin{array}{c}0.094 \\
(1.179)\end{array}$ & - \\
\hline WSTRUCTDUM & $\begin{array}{c}-0.067 \\
(-1.088)\end{array}$ & - \\
\hline LnDISSCHOOL & $\begin{array}{c}-0.071 \\
(-1.809)^{*}\end{array}$ & $\begin{array}{c}-0.068 \\
(-1.910)^{\star *}\end{array}$ \\
\hline LnDISHPITAL & $\begin{array}{c}-0.085 \\
(-1.980)^{\star *}\end{array}$ & $\begin{array}{c}-0.075 \\
(-1.885)^{*}\end{array}$ \\
\hline LnDISSPMARKET & $\begin{array}{c}0.023 \\
(0.560)\end{array}$ & - \\
\hline LnDISREST & $\begin{array}{l}-0.023 \\
(-0.652)\end{array}$ & - \\
\hline LnDISCITY & $\begin{array}{c}0.054 \\
(1.274)\end{array}$ & $\begin{array}{c}0.064 \\
(1.538)\end{array}$ \\
\hline LnDISMSTREET & $\begin{array}{c}0.024 \\
(1.030)\end{array}$ & - \\
\hline GARDENDUM & $\begin{array}{c}0.129 \\
(1.673)^{*}\end{array}$ & - \\
\hline LnCO & $\begin{array}{c}-1.305 \\
(-13.115)^{\star * *}\end{array}$ & $\begin{array}{c}-1.375 \\
(-15.066)^{\star * *}\end{array}$ \\
\hline $\begin{array}{l}\text { No. Observation } \\
\text { Adjusted R }{ }^{2}\end{array}$ & $\begin{array}{c}250 \\
0.766\end{array}$ & $\begin{array}{c}250 \\
0.763\end{array}$ \\
\hline
\end{tabular}

The main inferences of this analysis are given below:

(1) All the neighborhood and structural characteristics except building size, wall structure, number of rooms, distance from supermarket, distance from restaurant, distance from city, and distance from main street are statistically significant at 5 percent level of significance.

(2) The environmental characteristic, $\mathrm{CO}$, is negatively related to house price and it significant at 1 percent level. The results also confirm that as the level $\mathrm{CO}$ increases by one percent house price reduces by 1.375 percent on the average.

(3) Among the neighborhood characteristics, the distance from city positively related to property price. It showing that when distance increases, property price also increases.

(4) Distance from school or hospital are negatively related to house price, showing that the plots nearer the school or hospital have high property values.

(5) The plot area and bulding area are also positively related to property price.

The regression results of the hedonic price function shows that all the significant estimated variables follow the expected relationship pattern. Hence the estimated equation could be written as:

$$
\begin{aligned}
\ln \text { PPRICE }= & 2.783+0.528 \operatorname{lnLANDSIZE~+} \\
& 0.164 \ln \text { BUILDSIZE - } \\
& 0.068 \ln \text { DISSCHOOL - } \\
& 0.075 \ln \text { DISHPITAL - } \\
& 1.375 \ln \text { CO }+\mathrm{e}
\end{aligned}
$$

\section{Calculation of Implicit Marginal Price}

The first derivative of the hedonic price function can be interpreted as the implicit marginal price function for the environmental goods. Descriptive statistics of implicit marginal prices for 250 observations is given in the table 5.

Table 5. Descriptive statistics of Implicit Marginal Price

\begin{tabular}{lc}
\hline Descriptive Statistics & $\begin{array}{c}\text { Implicit Marginal Price } \\
\text { (Rupiahs) }\end{array}$ \\
\hline Mean & $20.592,0$ \\
Standard error & $1.133,2$ \\
Median & $15.147,9$ \\
Mode & $13.200,0$ \\
Standard deviation & $17.917,4$ \\
Minimum & $1.555,7$ \\
Maximum & $141.428,5$ \\
\hline
\end{tabular}


Hence the marginal implicit price for reducing CO is calculated as $\mathrm{Rp} 20.600,00$. This result clearly identifies air quality as an important factor, along with structural and neighbourhood characteristics, in determining demand for property transaction in Daerah Istimewa Yogyakarta.

\section{Implicit Demand Function}

As mentioned earlier, second stage estimation of inverse demand curve is conducted by regressing the implicit marginal price on the quantity of environmental goods purchased and other socio economic features including income level of the individuals. The results are given in table 6 .

Table 6. Estimation of Inverse Demand Function

\begin{tabular}{|c|c|c|}
\hline Variable & Full Model & Fit Model \\
\hline (Constant) & $\begin{array}{c}3.449 \\
(3.617)^{* * *}\end{array}$ & $\begin{array}{c}3.022 \\
(3.425)^{* * *}\end{array}$ \\
\hline INCOMELEVEL & $\begin{array}{c}0.097 \\
(1.515)\end{array}$ & $\begin{array}{c}0.079 \\
(1.351)\end{array}$ \\
\hline LnFAMEMBER & $\begin{array}{c}-0.079 \\
(-0.939)\end{array}$ & - \\
\hline LnLANDSIZE & $\begin{array}{c}0.551 \\
(7.819)^{* * *}\end{array}$ & $\begin{array}{c}0.533 \\
(7.727)^{* * *}\end{array}$ \\
\hline LnBUILDSIZE & $\begin{array}{c}0.104 \\
(1.266)\end{array}$ & $\begin{array}{c}0.147 \\
(1.863)^{*}\end{array}$ \\
\hline WALLSTRUCTDUM & $\begin{array}{c}-0.062 \\
(-0.998)\end{array}$ & - \\
\hline LnNUMROOM & $\begin{array}{l}0.083 \\
(1.015)\end{array}$ & - \\
\hline LnDISSCHOOL & $\begin{array}{c}-0.065 \\
(-1.640)\end{array}$ & $\begin{array}{c}-0.067 \\
(-1.889)^{*}\end{array}$ \\
\hline LnDISHOSPITAL & $\begin{array}{c}-0.085 \\
(-1.972)^{\star *}\end{array}$ & $\begin{array}{c}-0.080 \\
(-2.026)^{\star *}\end{array}$ \\
\hline LnDISSUPERMARKET & $\begin{array}{c}0.024 \\
(0.584)\end{array}$ & - \\
\hline LnDISRESTAURANT & $\begin{array}{c}-0.024 \\
(-0.685)\end{array}$ & - \\
\hline LnDISCITY & $\begin{array}{c}0.056 \\
(1.337)\end{array}$ & $\begin{array}{c}0.071 \\
(1.722)^{*}\end{array}$ \\
\hline LnDISMAINSTREET & $\begin{array}{c}0.031 \\
(1.292)\end{array}$ & - \\
\hline GARDENDUM & $\begin{array}{l}0.108 \\
(1.385)\end{array}$ & $\begin{array}{c}0.177 \\
(1.554)\end{array}$ \\
\hline LnCO & $\begin{array}{c}-0.317 \\
(-3.156)^{\star * *}\end{array}$ & $\begin{array}{c}-0.349 \\
(-3.766)^{\star * * *}\end{array}$ \\
\hline $\begin{array}{l}\text { No. Observation } \\
\text { Adjusted } \mathrm{R}^{2}\end{array}$ & $\begin{array}{c}250 \\
0.651\end{array}$ & $\begin{array}{c}250 \\
0.646\end{array}$ \\
\hline
\end{tabular}

The major inferences are:

(1) The first derivative of the implicit marginal price function with respect to $\mathrm{CO}$ is negative (0.349) signaling decreasing marginal implicit prices for increasing environmental quality. It means that in the study area, a reduction in $\mathrm{CO}$ by one percent leads to 0.349 percent increase in property values.

(2) The coefficient of number of family members, wall structure, distance from supermarket, and distance from main street are not significant.

(3) All other variables except number of family members, wall structure, distance from supermarket, and distance from main street are significant at 5 percent level of significance. It is interesting to note that the distance from city increases by one percent, residential property value enhances by 0,071 percent.

(4) Plot area and building area are positively related to residential property values.

So far we have explained the hedonic price function estimation and its implications to residential property values. The results indicate very clearly that the households are willing to pay for improved air quality. It is therefore necessary to estimate the welfare benefits accruing to them trough the purchase of property with reduced air quality.

\section{CONCLUSION}

The primary objective of this study was to establish the relationship between air quality and the residential property values di province of Daerah Istimewa Yogyakarta. By mapping the area which has highest concentration of $\mathrm{CO}$ earlier and estimating the hedonic property value in the area, we can establish the relationship between air quality and the residential property values.

In the model specification, we incorporated a number of structural, neighborhood, environmental and socioeconomic variables as determinants of consumer's willingness to pay for reduced air quality. We hypothesized that the major environmental variable $\mathrm{CO}$ is inversely related to the residential property values. Similarly, the presence of garden, distance from main street, distance from 
supermarket, plot area, and building area are positively related to property price while distance from hospital and distance from restaurant are negatively related.

By adopting a two-stage estimation procedure to estimate these relationships, we found that, on the average, an increase in the level of $\mathrm{CO}$ reduced property prices in the study area by 1.375 percent. We estimated the marginal implicit price for reducing CO as $\mathrm{Rp} 20.600,00$. Estimates further revealed that the households are willing to pay an additional amount of 0.35 percent for a reduction in $\mathrm{CO}$. In short, the analysis revealed a positive response of households in Daerah Istimewa Yogyakarta -which have highest concentration of $\mathrm{CO}$ - between air quality and property prices.

\section{REFERENCES}

Bajari, P and CL Benkard. 2005. "Demand Estimation with Heterogeneous Consumers and Unobserved Product Characteristics: A Hedonic Approach". Journal of Political Economy, 113(6), 1239-1276.

Bhattacharya, Rabindra, N. 2002. Environmental Economics: An Indian Perspective. New Delhi: Oxford University Press.

Boyle, M. and K. Kiel. 2001. “A Survey of House Price Hedonic Studies of the Impact of Environmental Externalities". Journal of Real Estate Literature. Vol. 9, No 2, pp. 117144.

Briggs, D.J.; de Hoogh, C.; Gulliver, J.; Wills, J.; Elliott, P.; Kingham, S.; Smallbone, K. 2000. "A Regression based Method for Mapping Traffic-related Air Pollution: Application and Testing in Four Contrasting Urban Environments." Sci Total Environ 253(1-3): 151-167.

Cicero-Fernandez, P.; Torres, V.; Rosales, A.; Cesar, H.; Dorland, K.; Munoz, R.; Uribe, R.; Martinez, A.P. 2001. "Evaluation of Human Exposure to Ambient PM10 in the Metropolitan area of Mexico City using a GISbased Methodology". J Air Waste Manag Assoc 51: 1586-1593.
Civis, S, Z. Zelinger, M. Strizik, Z. Janour. 2001. "Simulation of Air Pollution in a Wind Tunnel". In: Spectroscopy from Space. (Demaison, J., Ed.), Kluwer Academic, Dordrecht, 275-299.

Cowell PJ and Zeng TQ. 2003. "Integrating Uncertainty Theories with GIS for Modeling Coastal Hazards of Climate Change." Marine Geodesy, 26, 5-18.

Gualtieri G., \& Tartaglia M. 1998. Predicting Urban Traffic Air Pollution: a GIS framework, Transportation Research - D, 3(5), pp. 329-336, Elsevier Science.

Hoek, G.; Fischer, P.; Van Den Brandt, P.; Goldbohm, S.; Brunekreef, B. 2001. “Estimation of Long-term Average Exposure to Outdoor Air Pollution for a cohort study on mortality." J Expo Anal Environ Epidemiol 11(6): 459-469.

Holgate. 2002. Air Pollution and Health. Lancet, 360: 1233-1242.

Janour, Z., Z. Zelinger, S. Civis. 1999. "Laser Photoacoustic Spectrometry and its Application for Simulation of Air Pollution in a wind tunnel". Analyst, 124, 1205-1208.

Jones C B, Kidner D B, Luo L Q, Bundy Gl And Ware J M.. 1996. Database design for a Multi-scale Spatial Information System. Int. Journal of GIS, 10(8), pp.901-920.

Lave, L.B. and Seskin, E.P., 1972. "Air pollution, climate, and home heating: their effects on US mortality rates". Am J Public Health 62 7, pp. 909-916

Longley, P.A., M.F. Goodchild, D.J. Maguire, D.W. Rhind. 2001. "Geographic Information Systems and Science." John Wiley \& Sons, 27- 58, New York.

Moaz, Alsherfawi Aljazaerli. 2005. "Hedonic Valuation of Marginal Willingness to Pay for Air Quality in Metropolitan Damascus." Forum of International Development Studies, 3 September 2005.

Murty, M., S. Gulati and A. Banerjee. 2003. Hedonic Property Prices and Valuation of Benefits from Reducin Urban Air Pollu- 
tion in India. Institute of Economic Growth, Delhi University Enclave, pp. 127.

Ozkaynak, H. and Thurston, G.D. 1987. “Associations between 1980 US Mortality rates and Alternative Measures of Airborne Particle Concentration". Risk Anal 7 4, pp. 449-461.

P.K.Baby. 2003. "Economic Impacts of Air Pollution on Human Health and Property Values: A Study of Cochin Industrial Agglomeration". Thesis. Department of Applied Economics, Cochin University of Science and Technology. India.

Rashed, T. M. G. E. 2003. "Measuring the Environmental Context of Social Vulnerability to Urban Earthquake Hazards: An Integrative Remote Sensing and GIS Approach". University of California, Santa Barbara, PhD Thesis.Wood,
Rosen, Sherwin. 1974. "Hedonic Prices and Implicit Markets: Product Differentiation in Pure Competition". The Journal of Political Economy, Vol. 82, No. 1. (Jan. Feb.,1974), pp. 34-55.

Sh. Rahmatizadeh., et. al. 2009. "The Ant-Bee Routing Algorithm: A New Agent Based Nature-Inspired Routing Algorithm", Journal of Applied Sciences 9(5): 983 - 987. DOI.

Verstappen. 1983. Applied Geomorphological Surveys for Environmental Development. Elsevier, Sci., Publ, Comp. Amsterdam.

WHO. 2002. "Attributable Mortality by Risk Factor, Level of Development and Sex". Annex Table 9 in The World health Report, 2002. Geneva.

\section{APPENDIX}

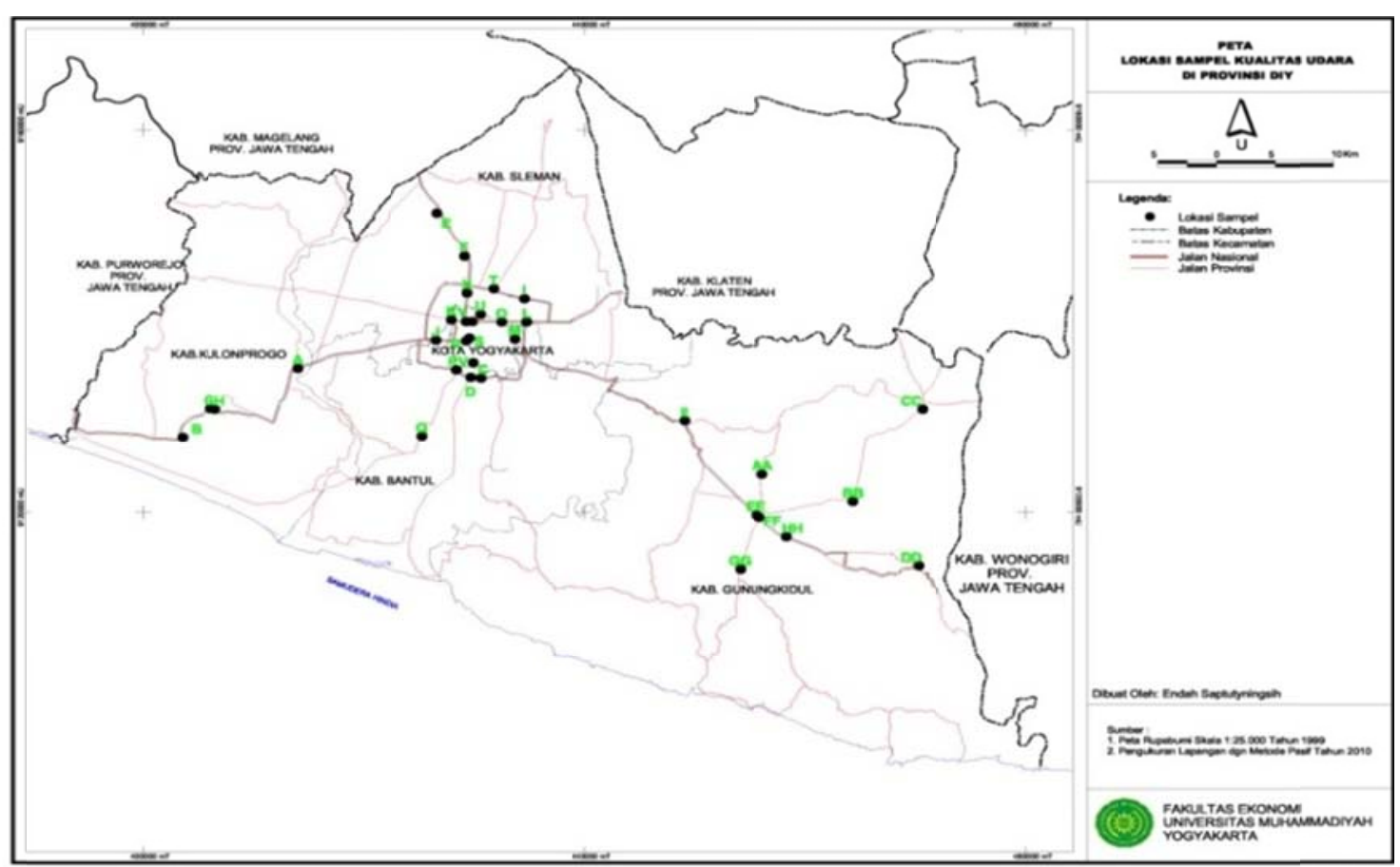

Figure 1. Sample Location of Air Quality in the Province of Daerah Istimewa Yogyakarta 


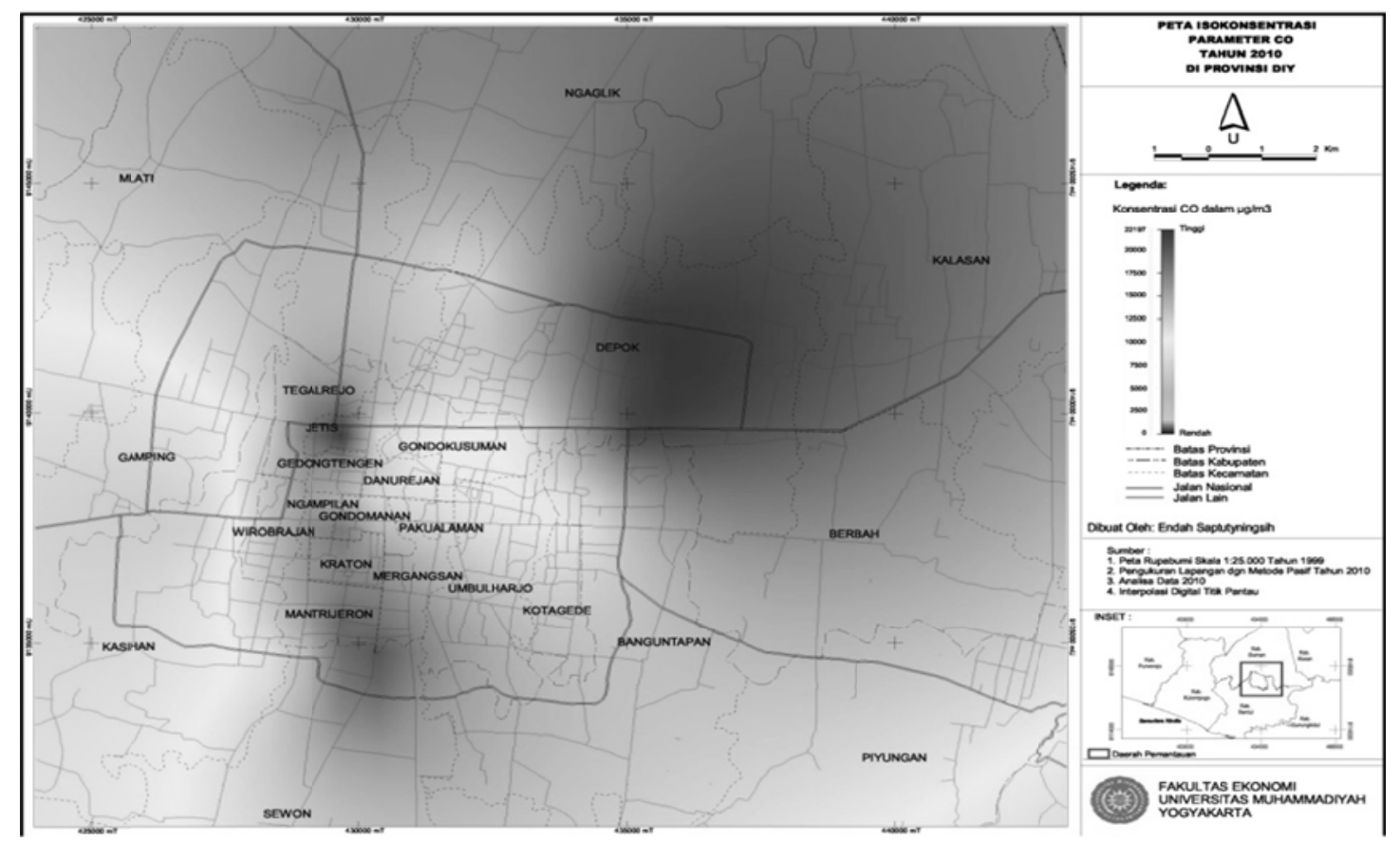

Figure 3. Isoconcentration Map of $\mathrm{CO}$ in the Areas that Have the Highest Concentration of $\mathrm{CO}$ in the Province DIY

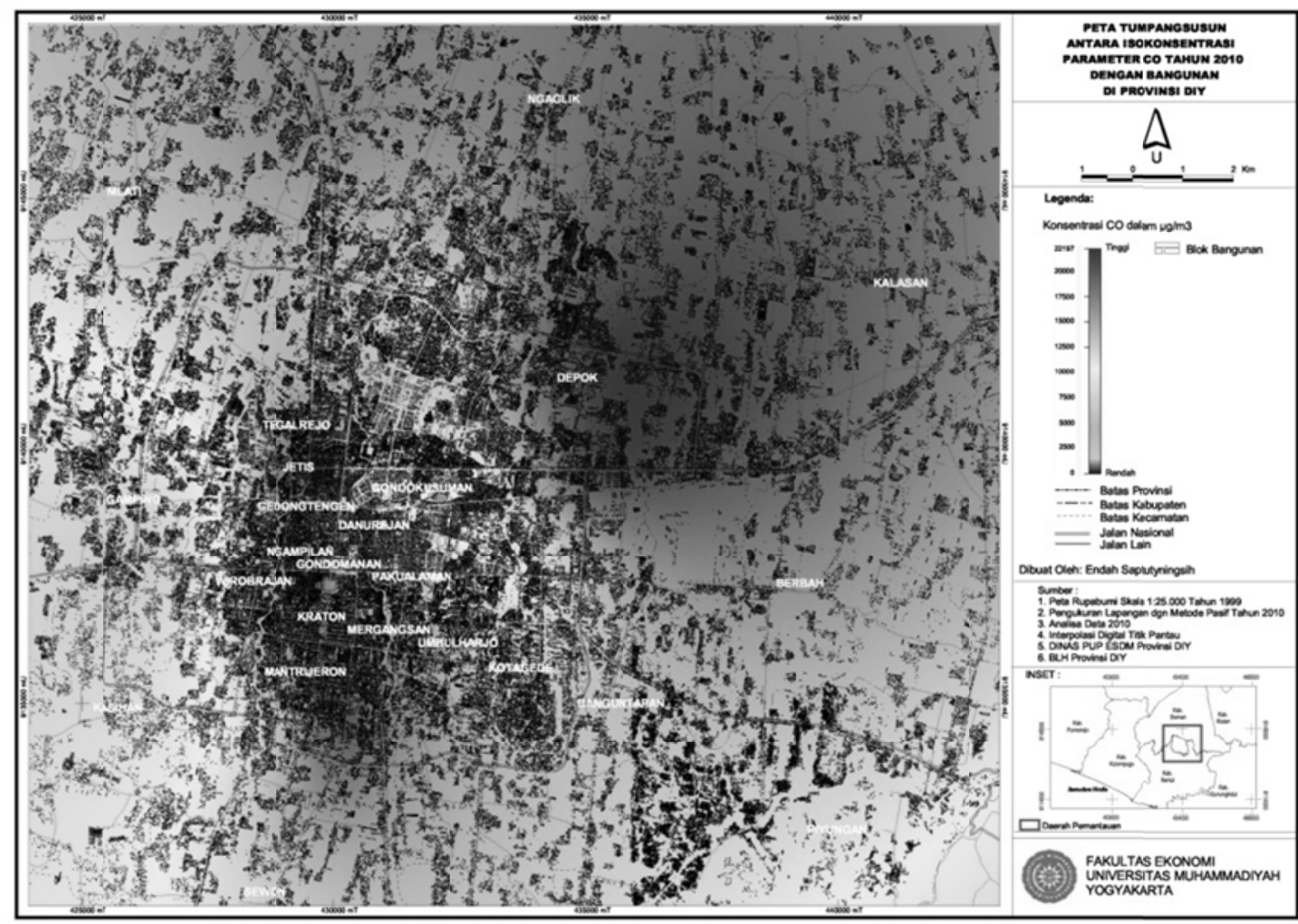

Figure 4. Overlay Map between Isoconcentration of $\mathrm{CO}$ and Building in the Areas that Have the Highest Concentration of CO in the Province of DIY 


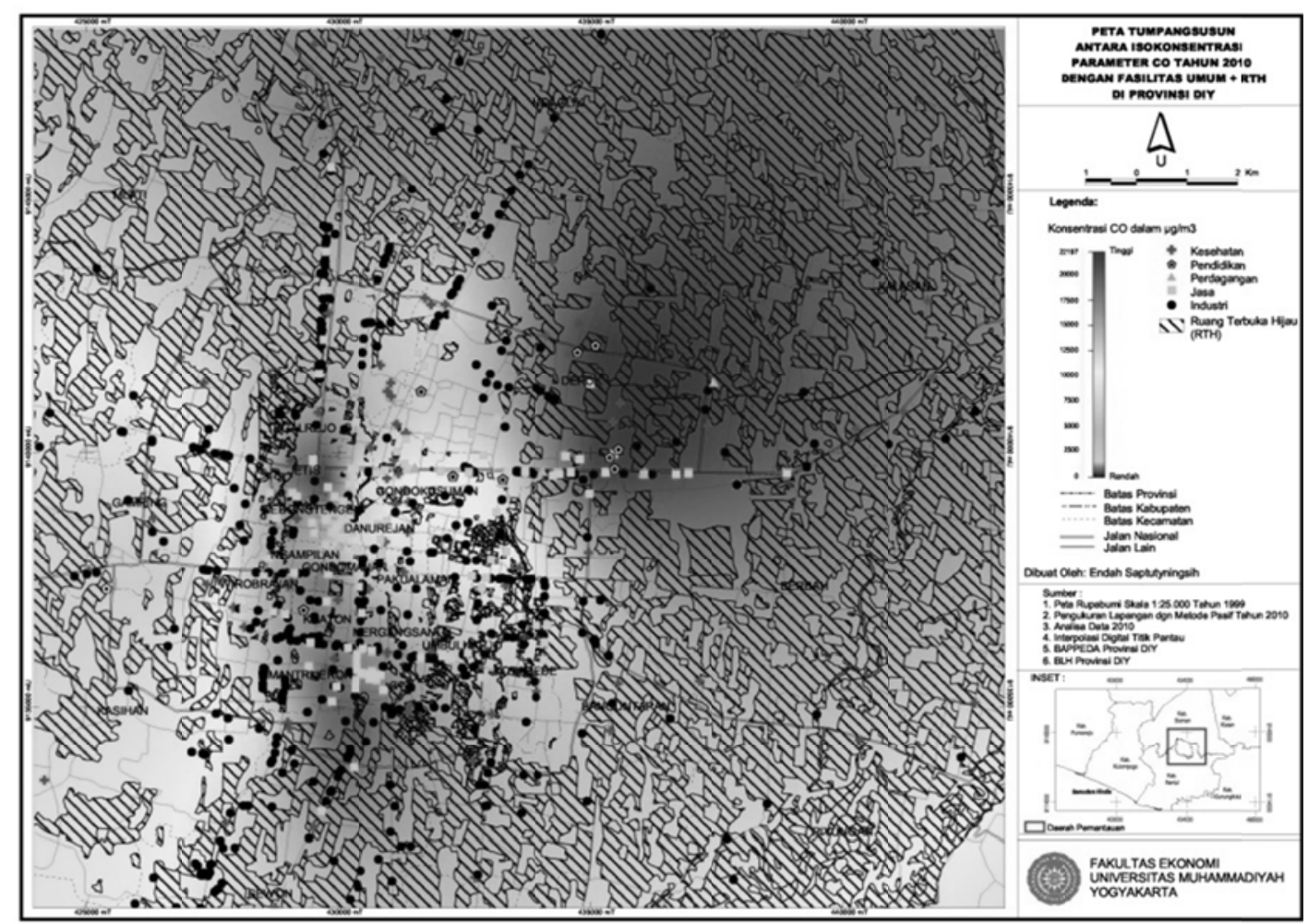

Figure 5. Overlay Map between Isoconcentration of CO and Public Facilities and Green Open Spaces in the areas that have the highest concentration of $\mathrm{CO}$ in the province of DIY 